\title{
ORLAND P. GIBSON $1914-1968$
}

by Angus H. Shortt, 101 Morier Ave., Winnipeg 8, Manitoba

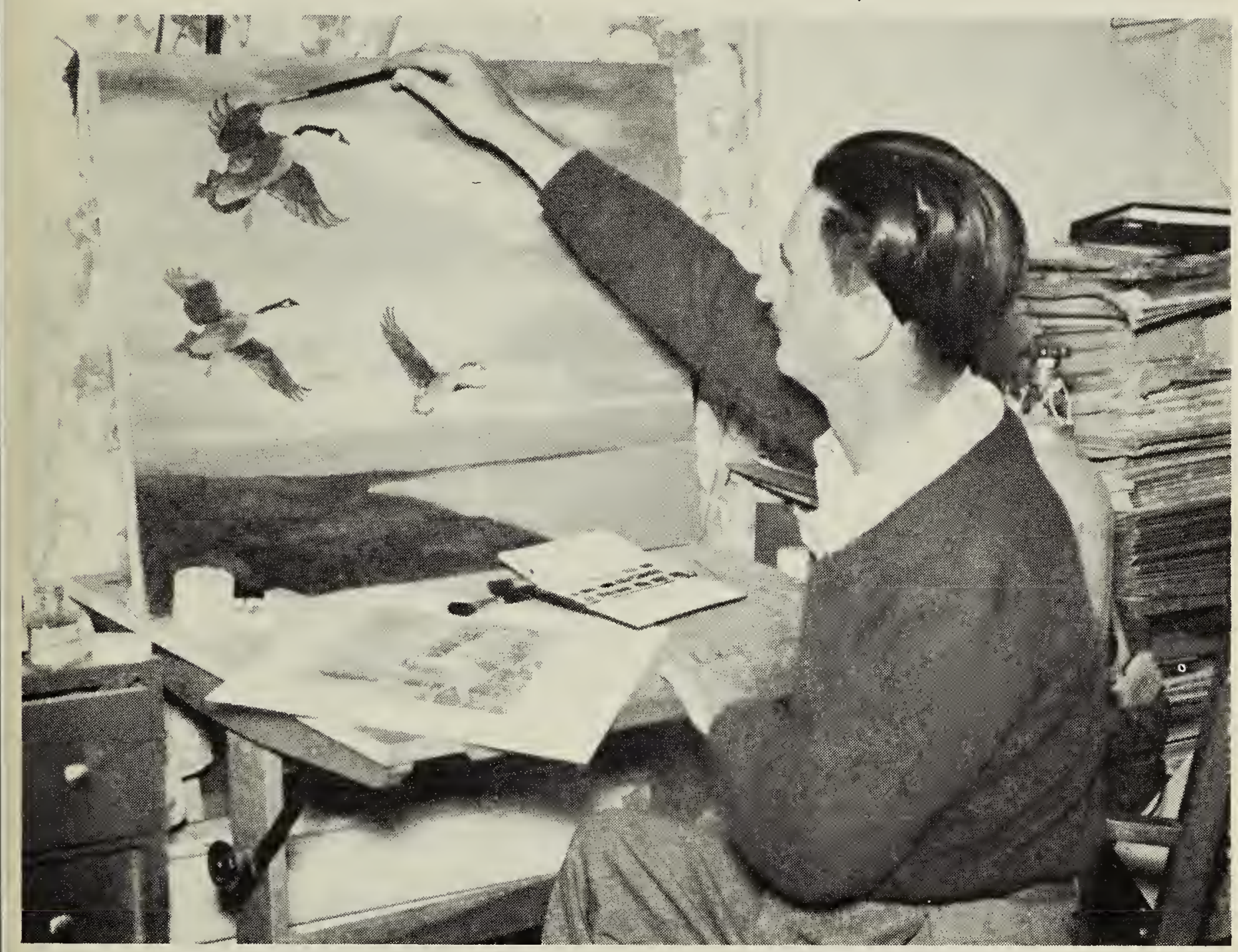

Orland P. Gibson, about 1963

With the death on January 10, 1968 of Orland P. Gibson, Manitoba lost one of its most highly regarded field ornithologists, a gifted bird artist and a keen botanist.

Orland was born in Winnipeg in 1914. Early in life he showed a keen interest in bird study and spent much time afield, often in company with his father who had a lodge on the Libau marshes at the south end of Lake Winnipeg. Here Orland developed a special interest in waterbirds and shorebirds in particular; these remained his prime favorites throughout his life.

A photographer and commercial artist by trade, he applied his skills in these media to his field sketching, bird painting and wild-flower photography. He became highly proficient in field identification of shorebirds in all their bewildering variation of plumage. He would spend hours studying a flock through his binoculars which he carried attached to a sturdy tripod

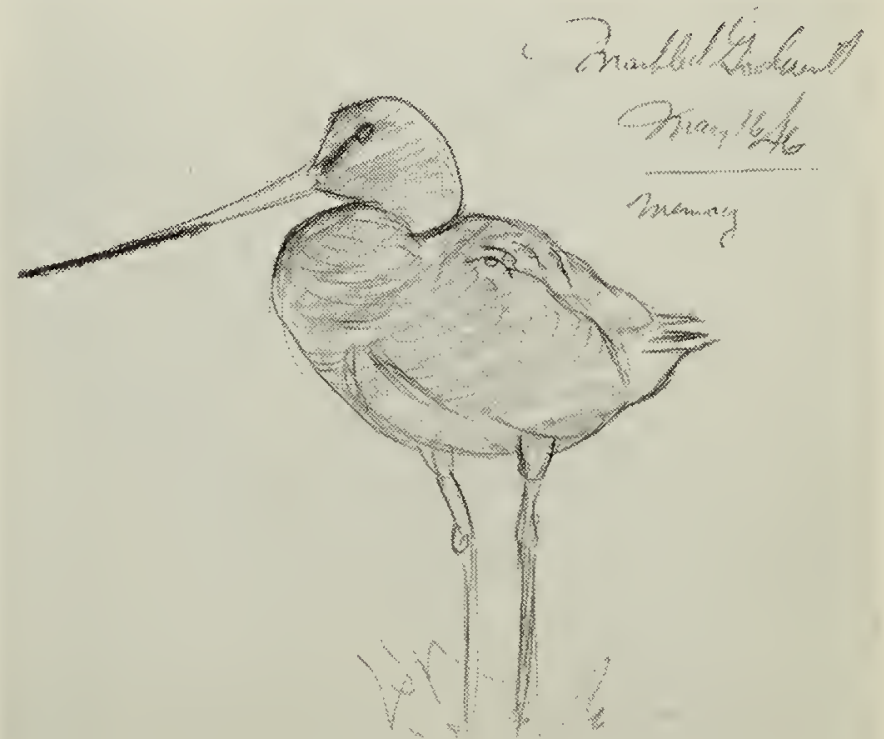

Marbled Godwit, May 16, 1946 


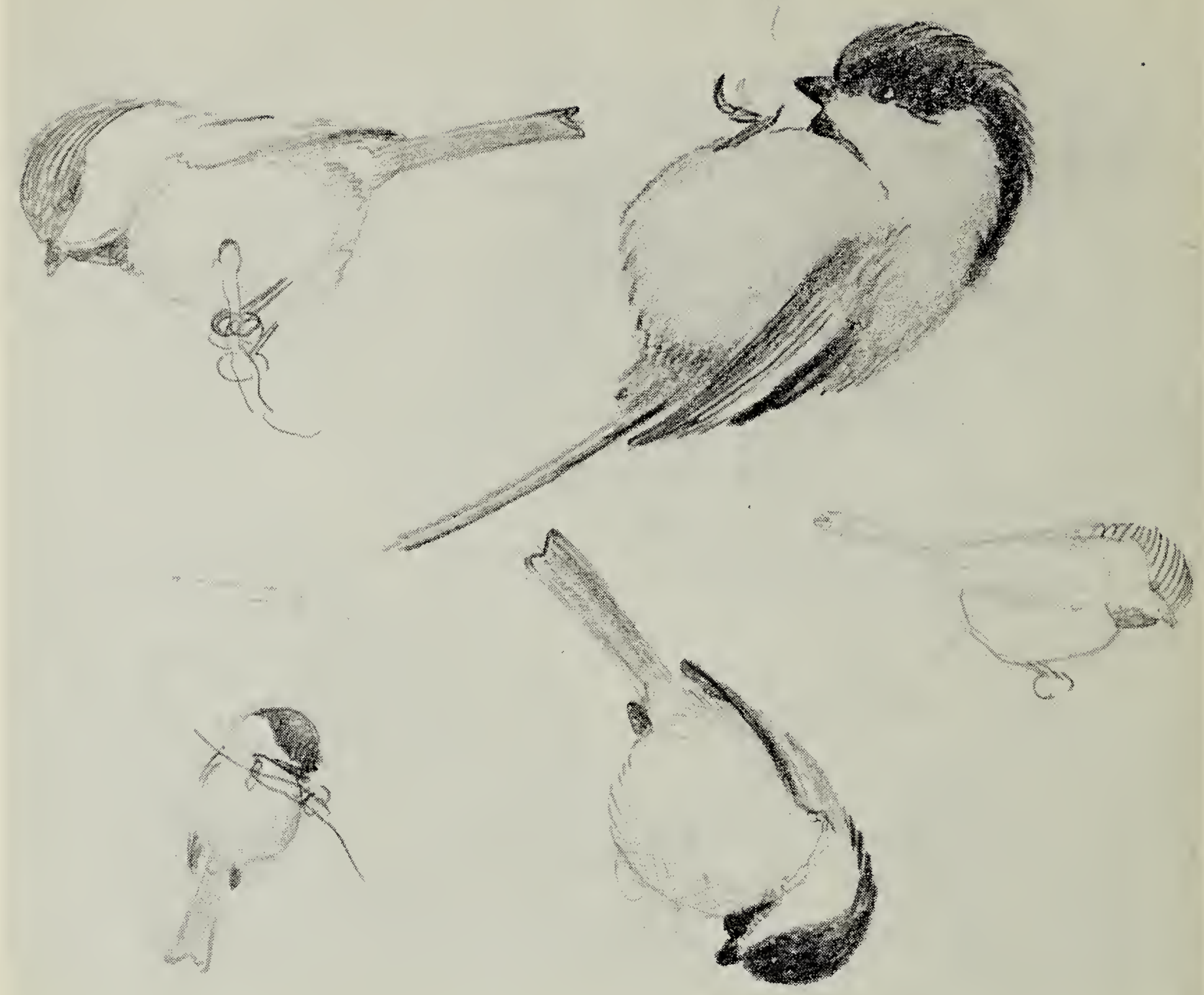

in order to free his hands for sketching. Many sketch books were filled with minute details of body contours, head and bill outlines and feather patterns. He had hoped some day to paint a series of Manitoba shorebirds.

Keen of hearing, he was familiar with the songs and call-notes of practically every bird found in and around our marshes and was quick to detect the presence of some strange note.

We recall vividly a midnight expedition into the Libau marshes with Orland and Ralph Fryer on June 30, 1935 to track down the origin of a mysterious night-caller. Armed with flashlights and .410 collecting guns, we stealthily manoeuvred until we converged on the spot where we judged the sound to originate. Luck was with us as a small bird flushed a short distance ahead of us and, held in the beams of our flashlights, was quickly collected. It proved to be the elusive Yellow Rail (Coturnicops noveboracensis). This specimen is now in the collection of the Manitoba Museum of Man and Nature.

Orland flung himself into nature study with a boundless enthusiasm. In later years his sketching and painting centred more on single species of birds; the Whistling Swan and Sandhill Crane are two that come to mind.

Mammals too, became an attraction for him and armed with his binoculars and cameras he covered many miles by car, canoe and on foot to obtain pictures of Moose and White-tailed Deer.

Modest and unassuming, he was reticent to put his sketches and paintings on display - he had many excellent ones of both birds and mammals. He strove for perfection in his work 
and was his own severest critic; if some particular part of a painting upon which he was at work failed to please him, that picture remained unfinished. He worked in oils, tempera, water-color and experimented with some of the new acrylic paints, but (at least to the writer) some of his most appealing work was in tempera.

His wife, Gertrude, shared his deep interest in nature and was his constant field companion. Working together they made an intensive study of Manitoba flora from 1956 to 1967, amassing a treasured collection of colour slides. They covered much of southern Manitoba in their search for rare and little-known plants. Orland was ever eager to explore new territory and every side road and trail that would accommodate a car was tackled. He knew more "out of the way" roads and trails than anyone else we have known. A well-thumbed copy of H. J. Scoggan's Flora of Manitoba was carried in the field and bore numerous marginal notes- a testimony to the accuracy of identiication which characterized his approach to nature study.

The year 1366 saw the culmination of several years' search for the different orchids native to Manitoba, when they found the last two on their list in the Sandilands area. These were Malaxis monophylla and Malaxis unifolia, insignificant little plants with tiny greenish-coloured flowers and known by the English name of Adder's Mouth. They reported their find to H. J. Scoggan in Ottawa who confirmed the rarity of the two species.

But the climax was still to come when, during the summer of 1967 they found them again, this time at Scanterbury. On this occasion they collected the plants and sent them to the National Herbarium in Ottawa, two rare additions to the record of Manitoba flora.

Orland was a member of the Natural History Society of Manitoba, the Manitoba Camera Club and the Winnipeg Cine Club.

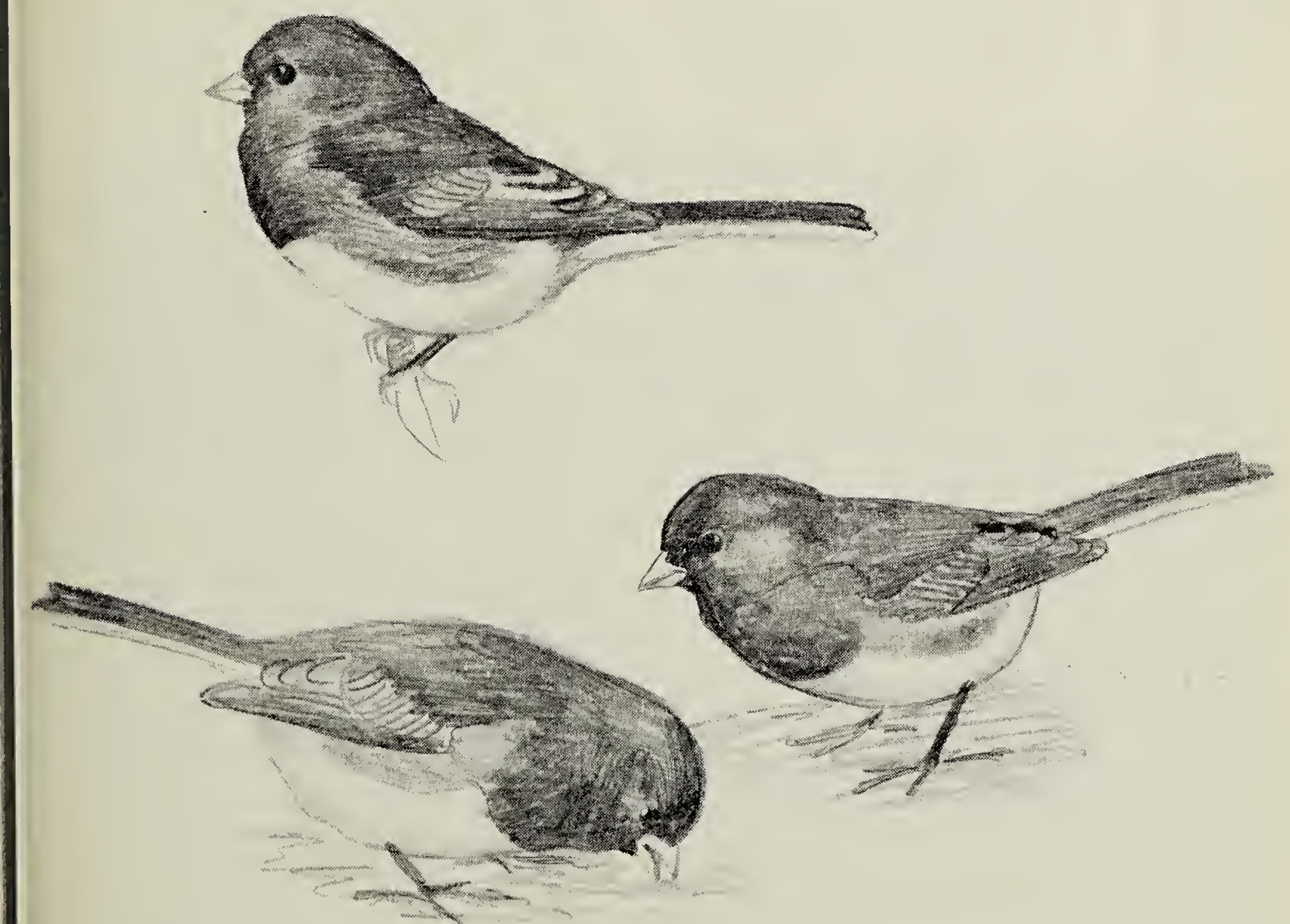

Slate-colored Junco, April 16, 1934

Sketches by O. P. Gibson

June, 1968 